\title{
Influence of maize particle size on kibble quality, palatability and metabolizability of diets for the Blue-fronted Amazon parrot (Amazona aestiva)
}

\author{
G.R. Werneck ${ }^{1}$, T.B. Moreno², C.M.M. Souza ${ }^{2}$, T.S. Bastos ${ }^{2}$, C. da Rocha ${ }^{3,4}$ and A.P. Félix ${ }^{3}$ \\ ${ }^{1}$ Municipal Zoological Park "Quinzinho de Barros", Sorocaba, 18.020-268, Brazil \\ ${ }^{2}$ Federal University of Paraná, Graduate in Animal Science, Curitiba, 80.035-050, Brazil \\ ${ }^{3}$ Federal University of Paraná, Department of Animal Science, Curitiba, 80.035-050, Brazil
}

KEY WORDS: geometric mean diameter, granulometry, parrots, wild nutrition

Received: 28 January 2020

Revised: $\quad 3$ March 2020

Accepted: 13 March 2020

${ }^{4}$ Corresponding author:

e-mail: chayane.ufpr@gmail.com

\begin{abstract}
The objective of this study was to evaluate the effect of four different maize particle sizes in extruded diets of uniform size on kibble characteristics, metabolizability and palatability of diets for the Blue-fronted Amazon parrot (Amazona aestiva). Eight birds were allocated according to a Latin Square design (4 diets $\times 4$ periods) which gave 8 replicates per treatment. Maize was ground with use of four different sieves (0.8,1.2, 2.6 and $4.2 \mathrm{~mm}$ diameter), generating particles with different geometric mean diameters (GMD): 528, 575, 628 and $830 \mu \mathrm{m}$, respectively. The extruded diets had the same diameter of $7 \mathrm{~mm}$. The variables evaluated were leftovers, daily intake, coefficients of total apparent metabolizability (CTAM) of dry matter (DM), crude protein (CP) acid-hydrolysed ether extract (AHEE) and gross energy (GE), as well as faecal DM content, and palatability of diets. The evaluated kibble characteristics were density, size, hardness and porosity. There was an increase in daily diet intake $(P<0.001)$ and reduction of leftovers amount $(P<0.001)$ when kibbles with maize particles with the largest GMD were fed to birds. There was an increase in CTAM of DM, $\mathrm{CP}, \mathrm{AHEE}$ and GE in response to maize particles GMD increase $(P<0.05)$. There was also a linear increase in the density of diets with an increase in size of maize particles. Birds preferred kibbles produced with use of maize particles with GMD of $830 \mu \mathrm{m}$ over kibbles based on particles of $528 \mu \mathrm{m}$ GMD. It can be concluded that maize particles with the largest size $(830 \mu \mathrm{m})$ may increase kibble density, improve feed preference and increase diet metabolizability when used in feed for the Blue-fronted Amazon parrot.
\end{abstract}

\section{Introduction}

The particle size of the ingredients or diets is determined after the processes of milling and sifting and is expressed by the geometric mean diameter (GMD) of the particles (Zanotto and Bellaver, 1996). According to research carried out on broilers by Zanotto et al. (1994), coarse maize grinding increased grinder yield up to $143 \%$ in comparison to fine maize grinding, and reduced electricity consumption by $61 \%$ with simultaneous no effect on nutrient digestibility and animal performance.

There is evidence that particles with larger size in the diet for birds can increase the secretion of hydrochloric acid in the proventriculus, stimulate gizzard functions, increase digesta retention time, promote longer enzymatic actions on food, and thus increasing the efficient of nutrients utilization 
(Nir et al., 1994; Ribeiro et al., 2002; Amerah et al., 2007). According to Amerah et al. (2007) the optimum feed particle size is between 600 and $900 \mu \mathrm{m}$ for broiler diets based on maize or sorghum. On the other hand, larger particles cause difficulties in the extrusion process reducing starch gelatinization (Bazolli et al., 2015).

Thus, in addition to affecting production costs and digestibility of the diet, the ingredients particle size can exert influence on the quality of kibbles. Therefore, it is important to determine the most suitable particle size of the ingredients for use in the parrots' diets enabling better absorption of nutrients and associated with reduced energy consumption as well as increased grinding efficiency and quality of the kibbles. Therefore, the objective of this study was to evaluate the influence of maize particle size on the metabolizability, palatability and kibble quality of Blue-fronted Amazon parrot (Amazona aestiva) diets composed of kibble with uniform size.

\section{Material and methods}

The experiment was approved by the Committee on Ethics in the Use of Animals of the Agrarias Sciences Setor of the Federal University of Paraná (Curitiba, Brazil) under protocol number 070/2015, and was also approved by SISBIO (System of Authorization and Information on Biodiversity), which granted authorization to collect biological material and conduct research in a federal conservation unit, under number 50618-1 from 2015.

\section{General setup}

Animals and accommodation. Eight healthy Blue-fronted Amazon parrots (Amazona aestiva) over the age of 10 years, males and females, out of moulting period, docile and adapted to captivity were involved in the study. The birds weighed $413.5 \pm 44.2 \mathrm{~g}$ and $420.5 \pm 48.1 \mathrm{~g}$ at the beginning and end of the experiment, respectively. The experimental assays were conducted at the São Paulo Zoo Foundation located in the city of São Paulo (Brazil).

The birds were housed in individual cages measuring $70 \times 40 \times 60 \mathrm{~cm}$ with a grid placed at the bottom, which allowed excreta and refused feed to be collected on the tray below and at the same time prevented birds from accessing these materials. Two perches were hung at a height of $20 \mathrm{~cm}$ in the lateral areas of the cage, while the feeder and drinker were placed in the middle. The room temperature and relative humidity were measured every morning and afternoon. The mean values obtained in the experimental period were $23.7 \pm 1.6{ }^{\circ} \mathrm{C}$ and $70.2 \pm 3.1 \%$, respectively.

Experimental diets. The experimental diets were similar in kibble size, metabolizable energy, nutrient composition and mineral content, but dif-fered in the grinding level of maize (Table 1). The diets were formulated according to the recommendations of the Association of American Feed Control Officials (AAFCO, 1998) for feeding pet birds.

Table 1. Ingredients, analysed and calculated chemical composition of diets containing maize particle with four different geometric mean diameters (GMD)

\begin{tabular}{|c|c|c|c|c|}
\hline Indices & \multicolumn{4}{|c|}{ Amount } \\
\hline \multicolumn{5}{|l|}{ Ingredients, $\%$} \\
\hline maize & \multicolumn{4}{|c|}{74.00} \\
\hline soyabean meal & \multicolumn{4}{|c|}{17.50} \\
\hline whole extruded soybean & \multicolumn{4}{|c|}{3.00} \\
\hline mineral-vitamin supplement ${ }^{1}$ & \multicolumn{4}{|c|}{3.00} \\
\hline soybean oil & \multicolumn{4}{|c|}{2.20} \\
\hline common white salt & \multicolumn{4}{|c|}{0.30} \\
\hline \multirow{2}{*}{$\begin{array}{l}\text { Analysed chemical composition, } \\
\% \text { of dry matter }\end{array}$} & \multicolumn{4}{|c|}{ GMD, $\mu \mathrm{M}$} \\
\hline & 528 & 575 & 628 & 830 \\
\hline crude protein & 16.07 & 16.23 & 16.30 & 16.91 \\
\hline acid-hydrolysed ether extract & 4.64 & 4.67 & 4.56 & 4.42 \\
\hline crude fibre & 1.67 & 1.62 & 1.69 & 1.68 \\
\hline acid detergent fibre & 4.14 & 4.18 & 4.16 & 4.12 \\
\hline neutral detergent fibre & 8.59 & 8.68 & 8.67 & 8.60 \\
\hline nitrogen-free extract & 63.96 & 66.47 & 65.72 & 65.01 \\
\hline ashes & 4.27 & 4.30 & 4.26 & 4.29 \\
\hline gross energy, kcal/kg & 4643 & 4603 & 4641 & 4615 \\
\hline \multicolumn{5}{|c|}{ Calculated chemical composition, $\%$ of dry matter } \\
\hline total lysine & \multicolumn{4}{|c|}{0.82} \\
\hline digestible lysine & \multicolumn{4}{|c|}{0.73} \\
\hline total methionine & \multicolumn{4}{|c|}{0.36} \\
\hline digestible methionine & \multicolumn{4}{|c|}{0.31} \\
\hline digestible methionine + cystine & \multicolumn{4}{|c|}{0.54} \\
\hline
\end{tabular}

${ }^{1}$ mineral-vitamin supplement provided per kg of diet: IU: vit. A 14.640, vit. D 5.850; mg: vit. E 187.5, vit. K 6.51, vit. $B_{1}(3.69 \mathrm{mg})$, vit. $B_{2} 9.75$, vit. $B_{3} 49.74$, vit. $B_{6} 27$, biotin 1.02 , vit. $C 111$, pantothenic acid 12.93 , folic acid 4.05; iron 93.08, manganese 37.5 , zinc 30.0, zinc chelated 27.0 , copper 8.4 , iodine 1.68 , selenium chelated 0.23 ; g: choline 1.35; $\mu \mathrm{g}$ : vit. B12 16.80, chromium 103

Maize underwent the milling process in hammer mills with different sieve diameters $(0.8,1.2$, 2.6 and $4.2 \mathrm{~mm}$ ), while other raw materials were milled to $0.8 \mathrm{~mm}$. After the milling processes, all raw materials from each experimental diet were mixed and then extruded. The diets were extruded in a single-screw extruder (EX-800; Exteec, Ribeirão Preto, SP, Brazil) at a feed rate of about $350 \mathrm{~kg} / \mathrm{h}$. The extrusion temperature ranged between 110 and $120{ }^{\circ} \mathrm{C}$. After extrusion, the diets were dried and 
cooled down to room temperature in a rotary kiln with continuous flow for $15 \mathrm{~min}$. The extruded diets had the same diameter of $7 \mathrm{~mm}$.

The geometric mean diameter (GMD) and geometric standard deviation (GSD) of ground maize were obtained according to the methodology described by Zanotto and Bellaver (1996). Therefore, the 100-g representative samples of ground maize were passed through a sieve stack on a sieve shaker (Tamis ${ }^{\circledR}$, Bertel Industry, São Paulo, Brazil) for $10 \mathrm{~min}$ at amplitude of 7. The sieve stack consisted of seven sieves with screens of different mesh sizes: 4000, 2000, 1200, 600, 300, 150 and $37 \mu \mathrm{m}$. Prior to analysis the sieves were dried at $105^{\circ} \mathrm{C}$ in an oven, cooled in a desiccator and individually weighed. After the shaking process, the amount of particles retained on each sieve was determined by subtracting the weight of the empty sieve from the weight of sieve together with the retained feed. GMD and GSD (in parentheses) obtained for maize particles were: 528 (1.4), 575 (1.4), $628(1.5)$ and $830(1.8) \mu \mathrm{m}$ for sieves with diameters of $0.8,1.2,2.6$ and $4.2 \mathrm{~mm}$, respectively.

\section{Kibble quality}

Kibble density was calculated using the mass to volume ratio of three samples for each treatment. The size of the kibbles, 50 samples per treatment, was measured using a digital caliper. The hardness, expressed in kgf, was obtained using an Ethik Technology 298 DGP durometer (Ethik Technology, São Paulo, Brazil) for 20 samples per treatment. All diets were subjected to scanning electron microscopy at $40 \times$ magnification to verify the porosity of the kibbles.

The normal distribution for density, size and hardness values was verified by the Shapiro-Wilk test, and the values with a positive test results were submitted to an analysis of variance (ANOVA) using the GLM procedures of the SAS statistical package (SAS Institute. Inc., Cary, NC, USA). The differences were considered significant when the F-test revealed differences at a 5\% probability level. The means were compared using the Tukey test at a probability level of 5\%. Regression analysis was conducted using the REG procedure of SAS statistical package including linear and quadratic trends. Porosity has simply been described.

\section{Feed ingestion and metabolizability assay}

Experiment protocol and laboratory analyses. Every day fifty grams of feed per bird (as fed) were fed in two equal portions at 07:00 and 17:00, for a period of 10 days, with a 5-day adaptation followed by 5 days of total excreta collection.
Water was offered ad libitum. The intake of diets was determined by recording the initial weight of the feed offered minus the sum of the final weight of the leftovers in the feeder and the weight of the waste in the collection trays.

Total excreta collection was carried out twice a day (at 07:00 and 17:00) for 5 consecutive days (i.e., from day 6 to day 10). The excreta was collected, weighed and stored in individual plastic pots in a freezer at $-14{ }^{\circ} \mathrm{C}$ for further laboratory analysis. Feathers, kibbles of feed and woodchips from the perch were removed from faeces before weighing and storage. During the period of excreta collection, the characteristics of fresh faeces consistency were assessed on the basis of faecal assessment according to Carciofi et al. (2006). Faecal consistency was evaluated on a scale of 0 to 4 , i.e.: $0=$ soft stools with loss of tubular shape, uncoiled; $1=$ soft stools with moderate loss of tubular shape, uncoiled; 2 = moderately soft and tubular-shaped stools, uncoiled; 3 = slightly soft and tubular-shaped stools, coiled; and 4 = solid, tubular-shaped stools, coiled.

At the end of the collection period, the excreta were thawed, homogenized and pooled into a single sample for each cage and period. The samples were then weighed and dried in a forced ventilation oven at $55^{\circ} \mathrm{C}$ for $72 \mathrm{~h}$. Diets and dry excreta were ground to a particle size of $1 \mathrm{~mm}$ and analysed for DM at $105{ }^{\circ} \mathrm{C}$, crude protein (CP, method 954.01), acidhydrolysed ether extract (AHEE, method 954.02), crude fiber (CF, method 962.10), acid detergent fibre, neutral detergent fibre, ash (method 942.05), calcium (Ca, method 984.27) and phosphorus (P, method 984.27), all according to the Association of Official Analytical Chemists (AOAC International, 1995). Gross energy (GE) was determined in a bomb calorimeter (Model 1261; Parr Instrument Co., Moline, IL, USA). All analyses were carried out in duplicate and repeated when variation was greater than $5 \%$.

Based on the obtained results, the coefficients of total apparent metabolizability (CTAM) of diets were determined:

CTAM $(\%)=[($ consumed nutrient - excreted nutrient) / consumed nutrient] $\times 100$.

For the calculation of the metabolizable energy (ME), the following equation was used:

$$
\begin{gathered}
\mathrm{ME}(\mathrm{kcal} / \mathrm{kg})=\mathrm{GE}(\mathrm{kcal} / \mathrm{kg}) \text { consumed with the } \\
\operatorname{diet}(\mathrm{DM}) \times \mathrm{CTAM}(\%) \text { of } \mathrm{GE} / 100 \text {. }
\end{gathered}
$$

Experimental design and statistical analysis. The birds were distributed according to a double Latin square $(4 \times 4)$, meaning four experimental diets and four periods, with eight replicates per treatment. Each experimental diet was randomly fed to two 
birds in each period, so that at the end of the experiment all birds had consumed all diets.

The data verified for normality (Shapiro-Wilk test) were submitted to analysis of variance (ANOVA) using the GLM procedure of SAS statistical package (SAS Institute Inc., Cary, NC, USA). The experimental unit was the individual animal. The sums of squares of the ANOVA were separated into animal, period and treatment effects. Differences were considered significant when the F-test revealed differences at a $5 \%$ probability level. Means were compared by the Tukey test at a probability level of 5\%. Regression analysis was conducted using the REG procedure of SAS statistical package including linear and quadratic trends. Non-parametric data were submitted to a Kruskal-Wallis test. The significance level was set to 0.05 .

\section{Palatability test}

Experimental procedures. The palatability test consisted of comparing the extruded diets based on maize ground using sieves with 0.8 or $4.2 \mathrm{~mm}$ diameter, which corresponded to maize particles with GMD of 528 and $830 \mu \mathrm{m}$ and GDS of 1.4 and $1.8 \mu \mathrm{m}$, respectively. Fifty grams of each feed (maize particle with GMD of 528 vs $830 \mu \mathrm{m}$; kibble size $7.1 \mathrm{vs} 7.0 \mathrm{~mm}$ ) were placed in two separate feeders once a day at 8:00, and the diets were available to the parrots for $24 \mathrm{~h}$ for two consecutive days. The position of the feeders was changed on the second day of the experiment in order not to condition the birds to the feeding site. The quantities of the supplied diets and leftovers were recorded in order to calculate the intake ratio according to the equation:

intake ratio $(\%)=[\mathrm{g}$ of consumed $\operatorname{diet} \mathrm{A}$ or $\mathrm{B} /$ $\mathrm{g}$ of total consumption $(\mathrm{A}+\mathrm{B})]$.

Experimental design and statistical analysis. The adopted design was completely randomized in order to compare diets based on maize particles with different GMD (528 vs $830 \mu \mathrm{m})$. Eight parrots were included in the test and data were collected for 2 days, which gave 16 replicates in total. Data were analysed using Student's t-test at 5\% probability.

\section{Results}

\section{Kibble quality}

It was observed that the density of the kibbles increased linearly with an increase of maize particles GMD $(P<0.05)$, while other variables (size and hardness) did not differ $(P>0.05)$ (Table 2). Additionally, the extruded diets with maize particles with higher GMD presented a smaller area of porosity (Table 2). There was a significant effect of maize particle size on kibble density $(P<0.05)$. The higher kibble density was observed when they were produced with use of maize particles with GMD of 628 and $830 \mu \mathrm{m}$ compared to kibbles produced with use of particles with GMD of 528 and $575 \mu \mathrm{m}$, with the lowest value for the kibbles extruded with the maize particles with GMD of $528 \mu \mathrm{m}$.

Table 2. Kibble parameters, area of pores and porosity of parrots diets containing maize particles with different geometric mean diameters (GMD)

\begin{tabular}{|c|c|c|c|c|c|}
\hline Indices & $\begin{array}{l}\text { Size, } \\
\text { mm }\end{array}$ & $\begin{array}{l}\text { Density, } \\
\text { g/l }\end{array}$ & $\begin{array}{l}\text { Hardness, } \\
\text { kgf }\end{array}$ & $\begin{array}{l}\text { Pores }{ }^{1} \text {, } \\
\%\end{array}$ & $\begin{array}{l}\text { Porosity }{ }^{1} \text {, } \\
\mathrm{mm}\end{array}$ \\
\hline \multicolumn{6}{|l|}{ GMD, $\mu \mathrm{m}$} \\
\hline 528 & 7.1 & $420^{c}$ & 4.07 & 7.19 & 5.32 \\
\hline 575 & 6.7 & $480^{b}$ & 3.13 & 7.62 & 5.82 \\
\hline 628 & 6.9 & $530^{\mathrm{a}}$ & 3.40 & 5.70 & 3.90 \\
\hline 830 & 7.0 & $510^{a}$ & 3.80 & 4.98 & 3.97 \\
\hline \multicolumn{6}{|l|}{$P$-value } \\
\hline F-test & 0.721 & 0.028 & 0.752 & - & - \\
\hline linear & 0.684 & 0.021 & 0.717 & - & - \\
\hline quadratic & 0.567 & 0.087 & 0.823 & - & - \\
\hline
\end{tabular}

${ }^{1}$ scanning electron microscopy, no statistic analysis was performed; a,b - means with different superscript letters within each column differ by Tukey test $(P<0.05)$

\section{Feed ingestion and metabolizability assay}

Particles GMD had no effect on the amount of kibbles dropped ( $P>0.05$ for waste). However, leftovers and feed intake behaved in a quadratic fashion with the increase of maize particles GMD $(P<0.05)$. Thus, there was a lower amount of leftovers and a higher voluntary daily intake per animal proportional to the maize particles GMD increase (Table 3). The CTAM of DM, CP, AHEE

Table 3. Leftover ( $g$ of feed in the feeder), waste ( $g$ of feed on the tray) and daily intake ( $\mathrm{g} / \mathrm{bird}$ ) in wet matter basis of Blue-fronted Amazon parrot $(A$. aestiva) fed diets containing maize particles with different geometric mean diameters (GMD)

\begin{tabular}{cccc}
\hline Indices & Leftover & Waste & Intake \\
\hline GMD,$\mu \mathrm{m}$ & & & \\
528 & $29.08^{\mathrm{a}}$ & 4.77 & $16.15^{\mathrm{b}}$ \\
575 & $32.98^{\mathrm{a}}$ & 3.13 & $13.89^{\mathrm{b}}$ \\
628 & $28.97^{\mathrm{a}}$ & 4.13 & $16.91^{\mathrm{b}}$ \\
830 & $23.25^{\mathrm{b}}$ & 2.39 & $24.36^{\mathrm{a}}$ \\
SEM & 4.39 & 2.44 & 3.84 \\
P-value & & & \\
F-test & $<0.001$ & 0.399 & $<0.001$ \\
linear & $<0.001$ & 0.205 & $<0.001$ \\
quadratic & $<0.001$ & 0.977 & $<0.001$ \\
\hline
\end{tabular}

SEM - standard error mean; ${ }^{a, b}$ - means with different superscript letters within each column differ by Tukey test $(P<0.05)$ 
and GE increased in a quadratic fashion with particles GMD $(P<0.001)$. All these results were more pronounced when birds were fed diet based on maize particles with GMD of $830 \mu \mathrm{m}$ compared to the other experimental treatments.

There was no difference between diets in ME content and the DM of the excreta $(P>0.05$, Table 4). Faecal scores did not differ between treatments (median $=2.5 ; P=0.999$, data not shown) and their values were between 2 and 4 , which is considered as normal (Loureiro et al., 2013).

Table 4. Coefficients of total apparent metabolizability (CTAM) of the dietary nutrients, metabolizable energy (ME, $\mathrm{kcal} / \mathrm{kg}$ ) and dry matter of the excreta (DME) of Blue-fronted Amazon parrot ( $A$. aestiva) fed diets containing maize particles with different geometric mean diameters (GMD)

\begin{tabular}{|c|c|c|c|c|c|c|}
\hline \multirow{2}{*}{ Indices } & \multicolumn{4}{|c|}{ CTAM, \% } & \multirow{2}{*}{$\begin{array}{l}\mathrm{ME}, \\
\mathrm{kcal} / \mathrm{kg}\end{array}$} & \multirow{2}{*}{$\begin{array}{l}\text { DME, } \\
\%\end{array}$} \\
\hline & $\mathrm{DM}$ & $\mathrm{CP}$ & AHEE & GE & & \\
\hline \multicolumn{7}{|l|}{$\mathrm{GMD}, \mu \mathrm{m}$} \\
\hline 528 & $72.4^{b}$ & $22.4^{b}$ & $76.6^{c}$ & $78.8^{b}$ & 3598 & 23.9 \\
\hline 575 & $71.6^{\mathrm{b}}$ & $22.6^{\mathrm{b}}$ & $76.6^{c}$ & $77.6^{\mathrm{b}}$ & 3589 & 24.2 \\
\hline 628 & $72.3^{b}$ & $23.0^{b}$ & $78.2^{b}$ & $77.7^{\mathrm{b}}$ & 3609 & 25.1 \\
\hline 830 & $75.8^{\mathrm{a}}$ & $27.6^{\mathrm{a}}$ & $80.9^{a}$ & $80.1^{\mathrm{a}}$ & 3712 & 25.7 \\
\hline SEM & 0.42 & 0.43 & 0.37 & 0.41 & 23.20 & 0.63 \\
\hline \multicolumn{7}{|l|}{$P$-value } \\
\hline F-test & $<0.001$ & $<0.001$ & $<0.001$ & 0.042 & 0.146 & 0.421 \\
\hline linear & $<0.001$ & $<0.001$ & $<0.001$ & 0.192 & 0.085 & 0.227 \\
\hline quadratic & $<0.001$ & $<0.001$ & $<0.001$ & 0.015 & 0.225 & 0.862 \\
\hline
\end{tabular}

DM - dry matter; CP - crude protein; AHEE - acid-hydrolysed ether extract; GE - gross energy; SEM - standard error mean; a,b - means with different superscript letters within each column differ by Tukey test $(P<0.05)$; regression equations: CTAM-DM $(\%)=0.01 \mathrm{x}+67.96$ $\left(R^{2}=0.83\right) ;$ CTAM-CP $(\%)=6 \mathrm{E}-05 x^{2}-0.06 x+37.66\left(R^{2}=0.99\right) ;$ CTAM-AHEE $(\%)=0.01 x+68.60\left(R^{2}=0.967\right) ;$ CTAM-GE $(\%)$ $=0.006 \mathrm{x}+74.45\left(\mathrm{R}^{2}=0.54\right) ; \mathrm{ME}(\mathrm{kcal} / \mathrm{kg})=0.41 \mathrm{x}+3361\left(R^{2}=0.93\right)$

\section{Palatability test}

There was a higher IR for the diet containing maize particles with GMD of $830 \mu \mathrm{m}(P<0.05)$ when compared to diet containing particles with GMD of $528 \mu \mathrm{m}$ (Table 5).

Table 5. Number of first visits to the feeder $(\mathrm{N})$ and intake ratio $(\mathrm{IR}$, mean \pm standard error) for parrots fed simultaneously two diets containing maize particles with different geometric mean diameters (GMD; 528 (A) vs $830 \mu \mathrm{m}(\mathrm{B})$ ) for two days

\begin{tabular}{lrl}
\hline Indices & $\mathrm{N}^{1}$ & $\mathrm{IR}^{3,4}$ \\
\hline $\mathrm{GMD}, \mu \mathrm{m}$ & & \\
$528(\mathrm{~A})$ & 4 & $0.23 \pm 0.05^{\mathrm{a}}$ \\
$830(\mathrm{~B})$ & 12 & $0.77 \pm 0.05^{\mathrm{b}}$ \\
\hline
\end{tabular}

${ }^{1} \mathrm{~N}$ for $\mathrm{A}+\mathrm{N}$ for $\mathrm{B}=16$ (observations for 8 birds conducted for 2 days); ${ }^{2} \mathrm{IR}$ of $\operatorname{diet} \mathrm{A}=$ intake $(\mathrm{g})$ of $\operatorname{diet} \mathrm{A} /$ total $(\mathrm{g})$ intake of $\operatorname{diets} \mathrm{A}+\mathrm{B} ;{ }^{3} \mathrm{IR}$ of diet $B$ is equal to $0.77(1-0.23) ; a, b-$ IR means with different letter are significantly different according to the $t$-test

\section{Discussion}

Fine granulation of ingredients with the use of sieves with holes of $1 \mathrm{~mm}$ in diameter or smaller is a common practice in the pet food manufacture. Although finer granulation results in lower production efficiency and higher energy costs, as well as in faster sieves and mills wear, many factories grind and incorporate this finer granulation to improve ingredients cooking and starch gelatinization during extrusion. Smaller particles exhibit a larger contact surface during extrusion, optimizing the effects of heat, moisture and pressure on dietary cooking and starch gelatinization, resulting in a more expanded and well-formed kibbles with a smooth surface (Bazolli et al., 2015; Peixoto et al., 2018). High density may indicate poorly expanded products with lower starch gelatinization (Camire, 2000), as evidenced by the high density and lower porosity of the diets based on maize particles with higher GMD in the present study.

In this study, an increase in feed intake was observed when birds were fed diet based on the largest maize particles. It should be noted that the size of the maize particle did not translate into the size of kibbles since all four diets had similar kibbles (diameter about $7 \mathrm{~mm}$ ). Daily feed intake ranged from $14.94 \mathrm{~g}(\mathrm{ME}=3598 \mathrm{kcal} / \mathrm{kg}$ diet $)$ to $22.54 \mathrm{~g}$ $(\mathrm{ME}=3711 \mathrm{kcal} / \mathrm{kg})$ per bird for diets with smaller $(528 \mu \mathrm{m})$ and larger $(830 \mu \mathrm{m})$ maize particles, respectively. Other studies on Blue-fronted Amazon parrots report rather similar values for the voluntary intake of extruded rations, ranging from $12.40 \mathrm{~g}$ to 26.80 g per bird per day (Carciofi 1996; Saad et al., 2007). Otherwise, Kalmar et al. (2007) observed that feed intake in African grey parrots (Psittacus erithacus) was not significantly altered by the size of particles in the tested diets (fine vs coarse particle size).

In addition to the increased voluntary intake of the diet based on particles with a higher GMD $(830 \mu \mathrm{m})$, the birds also preferred (intake ratio) this diet when given the option of choosing between diets in the palatability assay. The hardness of the diets was not alter in the present study, but diets containing the largest maize particles had a higher density, which may be related to bird preferences. According to Nir et al. (1994), the density and consistency of feed particles affect the sensory input affecting animal feed intake and performance. Psittacidae have an extremely strong beak for breaking seeds and nuts in the wilderness, and it is common for these birds to handle and break hard 
barks for food. Thus, they prefer foods that require more handling with the beak, tongue and feet (Rozek et al., 2010). Given that the birds not only preferred the diet containing larger particles of maize, but also had a higher frequency of first visits to the feeder containing this diet, they evidently had to be able to distinguish the diet with something other than touch or density assessment. They most likely used a different surface structure (including porosity) to guide their choice.

Besides preferences (intake ratio) over the kibbles made from maize particles with a larger GMD $(830 \mu \mathrm{m})$, the values of nutrient metabolizability were also higher for diets based on particles of this size, which is similar to the results reported by Saad et al. (2007) evaluating extruded diets for Bluefronted Amazon parrots. The authors reported DM metabolizability values from 70.4 to $73.2 \%$ and $\mathrm{ME}$ values from 3456 to $3743 \mathrm{kcal} / \mathrm{kg}$. However, Saad et al. (2007) observed higher protein metabolizability values (36.1 to $37.5 \%$ ) compared to those found in the present study (22.4 to $27.6 \%$ ). According to Svihus et al. (2002), the shortened duration of action of gizzard pepsin resulting from shorter transit time in the gizzard might explain the lower protein digestibility observed in chickens fed with finely ground feedstuffs.

In addition to the fact that coarse particles are released more slowly from the gizzard, birds exhibit considerable reflux (antiperistaltic movements) of the material from as far as the proximal ileum to duodenum and gizzard (Basha and Duke, 1999). The gizzard of birds is a primary controller of food passage in the foregut (Chaplin et al., 1992). The gizzard coordinates the proventriculus (glandular stomach) and duodenum spasms with its own contractions to distribute the ingested food in a continuous flow to the lower gut (Duke, 1982; Chaplin and Duke, 1990). This back-and-forth movement is mainly stimulated by larger particles in the gizzard (Dukes, 2006) and a larger particle size diets have a longer retention time in the gastrointestinal tract, increasing the duration of action of digestive enzymes on the nutrients and their absorption in the intestine of chickens (Nir et al., 1994). Thus, the impact of feed particle size on apparent metabolizability coefficients can be explained by its influence on the rate of passage through the gastrointestinal tract, which in turn results in altered digestion and absorption times of nutrients (Kalmar et al., 2007).

Another factor that may exert influence on nutrient metabolizability is the gelatinisation process of starch granules. Abd El-Khalek et al. (2009) evaluated the effect of the obtained during extrusion starch gelatinisation degree (high vs low) on digestibility and observed that a lower degree of starch gelatinisation in extruded diets increased apparent crude protein digestibility in pigeons. According to these authors, higher protein digestibility in pigeons fed diet with starch of low gelatinization rate may result from increased pepsin activation by lower gastrointestinal tract $\mathrm{pH}$. In addition, the lower apparent crude protein digestibility observed in pigeons fed high-gelatinised pellets may be caused by excessive processing of the feed during heating, which leads to amino acid damage. In particular, lysine binds to sugars during the Maillard reaction.

\section{Conclusions}

Larger particle sizes may result in increased density and reduced porosity of kibbles, resulting in an extrudate considered to be of lower quality. The obtained results showed, however, that the supply of kibbles made from larger size maize particles (with geometric mean diameters of $830 \mu \mathrm{m}$ ) led to a higher feed intake and metabolizability of nutrients, without increasing feed waste in the Bluefronted Amazon parrots. Considering the energy saving due to the lack of the necessity of grinding maize very finely, it can be suggested that extruded diets for Blue-fronted Amazon parrots may contain larger particles of maize, which will ensure proper optimization of resource use.

\section{Acknowledgements}

The authors would like to thank the Academic Publishing Advisory Center (Centro de Assessoria de Publicação Acadêmica - CAPA) of the Federal University of Paraná (Brazil) for language support for this version of the article and Biotron Zootecnica Company for support the feed manufacture process.

\section{References}

AAFCO (Association of American Feed Control Officials), 1998. Nutrition Expert Panel Review: New rules for feeding pet birds. Feed Manag. 49, 23-25

Abd El-Khalek E., Kalmar I., Van Weyenberg S., Werquin G., Janssens G.P.J., 2009. Effect of starch gelatinization on nutrient digestibility and plasma metabolites in pigeons. J. Anim. Physiol. Anim. Nutr. 93, 359-365, https://doi. org/10.1111/j.1439-0396.2008.00868.x 
Amerah A.M., Ravindran V., Lentle R.G., Thomas D.G., 2007. Influence of feed particle size and feed form on the performance, energy utilization, digestive tract development, and digesta parameters of broiler starters. Poult. Sci. 86, 2615-2623, https://doi.org/10.3382/ps.2007-00212

AOAC International, 1995. Official Methods of Analysis of AOAC International. $16^{\text {th }}$ Edition. Arlington, VA (USA)

Basha M.E., Duke G.E., 1999. Effect of fasting on small intestinal antiperistalsis in the Nicholas turkey (Meleagris gallopavo). J. Exp. Zool. 283, 469-477, https://doi.org/10.1002/(SICI)1097010X(19990301/01)283:4/5<469::AID-JEZ17>3.0.CO;2-J

Bazolli R.S., Vasconcellos R.S., de-Oliveira L.D., Sá F.C., Pereira G.T., Carciofi A.C., 2015. Effect of the particle size of maize, rice, and sorghum in extruded diets for dogs on starch gelatinization, digestibility, and the fecal concentration of fermentation products. J. Anim. Sci. 93, 2956-2966, https:// doi.org/10.2527/jas.2014-8409

Camire M.E., 2000. Chemical and nutritional changes in food during extrusion. In: M.N. Riaz (Editor). Extruders in Food Applications. CRC Press. Boca Raton, FL (UA), pp. 127-147

Carciofi A.C., 1996. Evaluation of a diet based on seeds and fruits for parrots (Amazona sp): determination of food selectivity, consumption, nutritional composition, digestibility and metabolizable energy (in Portuguese: Avaliação de dieta à base de sementes e frutas para papagaios (Amazona $s p)$ : determinações da seletividade dos alimentos, consumo, composição nutricional, digestibilidade e energia metabolizável). MSc Dissertation. University of São Paulo. São Paulo (Brazil)

Carciofi A.C., Duarte J.M.B., Mendes D., de Oliveira L.D., 2006. Food selection and digestibility in yellow-headed conure (Aratinga jandaya) and golden-caped conure (Aratinga auricapilla) in captivity. J. Nutr. 136, 2014S-2016S, https://doi.org/10.1093/ jn/136.7.2014S

Chaplin S.B., Duke G.E., 1990. Effect of denervation of the myenteric plexus on gastroduodenal motility in turkeys. Am. J. Physiol. 259, G481-G489, https://doi.org/10.1152/ ajpgi.1990.259.3.G481

Chaplin S.B., Raven J., Duke G.E., 1992. The influence of the stomach on crop function and feeding behavior in domestic turkeys. Physiol. Behav. 52, 261-266, https://doi.org/10.1016/00319384(92)90268-7

Duke G.E., 1982. Gastrointestinal motility and its regulation. Poult. Sci. 61, 1245-1256, https://doi.org/10.3382/ps.0611245

Dukes H.H. 2006. Dukes' Physiology of Domestic Animals. (in Portuguese: Fisiologia dos Animais Domésticos). Guanabara Koogan. Rio de Janeiro (Brazil)

Kalmar I.D., Werquin G., Janssens G.P.J., 2007. Apparent nutrient digestibility and excreta quality in African grey parrots fed two pelleted diets based on coarsely or finely ground ingredients. J. Anim. Physiol. Anim. Nutr. 91, 210-216, https://doi. org/10.1111/j.1439-0396.2007.00694.x
Loureiro B.A., Prado P.L., Ballestero M.C.M., Judice M.A.P., Sá F.C., Carciofi A.C., 2013. Granulometry of the extruded food ingredients and digestibility and fecal parameters of wild parrot (Amazona aestiva) (in Portuguese: Granulometria dos ingredientes de alimento extrusado e digestibilidade e parâmetros fecais de papagaio-verdadeiro (Amazona aestiva)). In: Proceedings of the V International Congress on Pet Nutrition and XII Symposium on Pet Nutrition. Campinas (Brazil)

Nir I., Hillel R., Shefet G., Nitsan Z., 1994. Effect of grain particle size on performance: 2. Grain texture interactions. Poult. Sci. 73, 781-791, https://doi.org/10.3382/ps.0730781

Peixoto M.C., Ribeiro E.M., Maria A.P.J., Loureiro B.A., di Santo L.G., Putarov T.C., Yoshitoshi F.N., Pereira G.T., Sá L.R.M., Carciofi A.C., 2018. Effect of resistant starch on the intestinal health of old dogs: fermentation products and histological features of the intestinal mucosa. J Anim Physiol Anim Nutr. 102, e111-e121, https://doi.org/10.1111/jpn.12711

Ribeiro A.M.L., Magro N., Penz Jr. A.M., 2002. Corn particle size on broiler grower diets and its effect on performance and metabolism. Rev. Bras. Cienc. Avic. 4, 47-53, https://doi. org/10.1590/S1516-635X2002000100006

Rozek J.C., Danner L.M., Stucky P.A., Millam J.R., 2010. Oversized pellets naturalize foraging time of captive Orangewinged Amazon parrots (Amazona amazonica). Appl. Anim. Behav. Sci. 125, 80-87, https://doi.org/10.1016/j. applanim.2010.03.001

Saad C.E.P., Ferreira W.M., Borges F.M.O., Lara L.B., 2007. Voluntary intake of commercial foods and sunflower seed for blue-fronted parrot (Amazona aestiva). Cienc. Agrotecnol. 31, 1176-1183, https://doi.org/10.1590/S1413-70542007000400034

Svihus B., Hetland H., Choct M., Sundby F., 2002. Passage rate through the anterior digestive tract of broiler chickens fed on diets with ground and whole wheat. Br. Poult. Sci. 43, 662-668, https://doi.org/10.1080/0007166021000025037

Zanotto D.L., Albino L.F.T., Brum P., 1994. Effect of the degree of grinding on the energy value of corn for broilers (in Portuguese: Efeito do grau de moagem no valor energético do milho para frangos de corte). In: Proceeding of the Annual Meeting of the Brazilian Society of Zootechnics, Maringá, Paraná (Brazil), p. 57

Zanotto D.L., Bellaver C., 1996. Method of determining the particle size of ingredients for use in pig and poultry diets (in Portuguese: Método de determinação da granulometria de ingredientes para uso em rações em suíno e aves). EMBRAPA-CNPSA. Technical Communication no 215, p. 5 